\title{
Narratíva és pedagógiatörténet: egy lehetséges kutatási szemléletmód
}

\author{
BAlog BeÁta És Szabolcs Éva
}

ELTE PPK

\begin{abstract}
A narrativitás fogalmának, jelentéseinek különböző értelmezése a társadalomtudományok területén hazánkban is elterjedtnek mondható. A narratív szemléletmód elméleti és kutatásmetodológiai megközelítésének értelmezése hozzájárulhat a társadalomtudományi kutatások határainak tágításához. A múlt lehetséges olvasatainak felmutatása meg is kívánja, hogy különböző megközelítésekkel, módszeregyüttesekkel közelítsünk elmúlt korszakok világához. Tanulmányunkban a narratíva értelmezésének lehetőségeit és néhány hazai narratívákra épülő, pedagógiatörténeti kutatást kívánunk ismertetni azzal a céllal, hogy rámutassunk a történeti kutatások fontos eszközeként értelmezhető nyelvi eszközök felhasználhatóságára. Ezzel ráláthatunk arra, hogy a narratívák kutatói interpretálása révén megérthetjük vagy más nézőpontból láthatjuk a múlt egy vizsgált időszakának hatását, „hétköznapi emberek" élményeinek feltárásával értelmezhetjük az adott történelmi kor eseményeit.
\end{abstract}

Kulcsszavak: narratíva, pedagógiatörténet, múltértelmezés

A narratíva kifejezés ma már olyan elfogadott terminus, amely számos jelentéssel fordul elő a legkülönbözőbb társadalomtudományi munkákban. A narratív szemléletû́ kutatások társadalomtudományi elfogadottságát jól jelzik az újabb és újabb összefoglaló munkák e kutatási megközelítésról (Holstein és Gubrium, 2012; Squire és Tamboukou, 2012; Kim, 2016). A narratívával kapcsolatos hazai társadalomtudományi reflexiók gazdagságát a hazai szakirodalomban jól példázza a Narratívák könyvsorozat 11 kötete, de ide sorolható Pászka Imre monográfiája is (2007).

A narratíva pedagógiatörténeti jelenlétét Szabolcs Éva tanulmánya (2016) szemlézte, és utalt olyan pedagógiai és történettudományi előzményekre is, amelyek felkeltették a hazai kutatók figyelmét (White, 1973; Gyáni, 2000; Bruner, 2005). A témában az egyik leggyakrabban idézett történész Hayden White, aki szerint a történeti kutatás eredménye egy nyelvi kompozíció, amelyben a kiválasztott nyelvi eszközök nem stiláris jelentőségúek, hanem hordozzák a történetkutatás lényegét (Gyáni, 2000. 22. o.; White, 1984). White négyféle narratívaértelmezésre hívja fel a figyelmet: $a /$ az analitikus filozófusok, például Danto, a narratíva 
ismeretelméleti státuszával foglalkoznak, és azt kifejezetten a történeti jelenségek magyarázatára, értelmezésére alkalmas megközelítésnek tartják (vö. Rüsen, 1999); b/ az Annales-kör tagjai a narratív történetírást ideológiai reprezentációs stratégiának és nem tudományos megközelítésnek értelmezik; $c$ / a jeltudományi kiindulású értelmezés (pl. Foucault, Derrida, Genette) a narratív megnyilatkozásokat diszkurzív kódnak tartja, amely a beszélő pragmatikus szándéka szerint lehet a „valóság” reprezentációja; $d$ / a hermeneutikai megközelítés (Gadamer, Ricoeur) a diskurzusban megmutatkozó időtudatosságot, az idő strukturálását láttatja a narratívában (White, 1984; idézi: Szabolcs, 2016).

Ez a felosztás fogódzót nyújthat a tájékozódáshoz, de látnunk kell, hogy számos vitatott narratívaértelmezés létezik a társadalomtudományos diskurzusban, és sok esetben ernyőfogalomként használatos (Andrews, Squire és Tamboukou, 2012. 2-5. o.). Számos kutató a narratíva fogalmának, jelentéstartományának történettudományi értelmezéseit boncolgatva arra az elsősorban ismeretelméleti alapállásra helyezkedik - White említett felosztásában ez az első kategóriát jelenti -, hogy a narrativitásnak, az elbeszélésnek kitüntetett szerepe van a történeti kutatásban és a történetírásban: nem feltétlenül állítható szembe a tudományos megközelítéssel, hiszen a történeti elbeszélés „,az időtapasztalás cselekvésirányító és identitásképző" értelmezésének fogható fel (Rüsen, 1999. 42. o.). A történeti narratíva tudományos jellegét még abban is látja Rüsen, hogy a források, tények interpretációja „módszertanilag szabályozható és - az igazság biztosítása érdekében - szabályozandó kognitív folyamat.” (Rüsen, 1999. 43.o.). A történetírás által létrehozott narratív konstrukciók, értelmezések összefonódnak a retorikai eszközökkel, nyelvi formákkal. A posztmodern felfogás szerint tehát a történetkutatás folyamata különbözik a pozitivista tudományosságtól, de a forrásokból feltárt tények történetbe illesztése tudományosnak tekinthető abban az értelemben, hogy racionális megismerésre épül, kognitív folyamatok révén hozza létre az elbeszélést, narratívát mint kutatási produktumot. E felfogás szerint tehát a múltat kutató történész által létrehozott szaktudományos értekezés maga is narratíva, egy lehetséges, megalkotott olvasata a múltnak. Ez az értelmezés jól illeszkedik abba a felfogásba, hogy a történeti múltról különböző olvasatokat, a történeti „valóság” különböző reprezentációit tudjuk megalkotni történészként, mintegy jelentéssel ruházzuk fel azt.

A narratív szemlélet értelmezése azt is jelentheti, hogy olyan személyes forrásokat, emlékezetre épülő visszaemlékezéseket kutat a történész, amelyek maguk is narratívának, elbeszélésnek tekinthetőek. Ebben az esetben a különböző idősíkok találkozása valósul meg: a visszaemlékezésben megjelenő múlt, a visszaemlékezés ideje és minderről a történeti kutató által létrehozott narratíva ideje (Golnhofer és Szabolcs, 2009b).

A nemzetközi és a hazai pedagógiatörténeti kutatások a legutóbbi évtizedekben tematikájukban és kutatásmódszertani eszköztárukban is kitágultak (Biró és K. Pap, 2007; Pukánszky, 2008). Néhány hazai kutatási példa megmutatja, hogy a narratív szemlélet milyen módon, milyen elméleti és/vagy módszertani 
tudatossággal öltött testet a pedagógia történeti jelenségeit vizsgáló tudományterületen. A narratív kutatást mint ernyőfogalmat (Fulda, 2014) érdemes ismét hangsúlyozni e rövid szemlézéskor, hiszen nem győzzük kiemelni, hogy számos kutatásmódszertani megoldás adódik a narratív szemléletben rejlő kutatási lehetőségek érvényre juttatására.

Dombi Alice tanulmánykötetében (Dombi, 2012) 19. századi pedagógiai narratívákat ismertet a pedagógiai professzionalizáció alakulását igazolandó. A Nevelői szerep-narratívák c. fejezetben egyrészt a korszakban jelenlévő gyermekről alkotott képet ábrázolja, másrészt és ehhez kapcsolódóan a nevelővel, pedagógussal kapcsolatos szerepelvárásokat is kiemeli. Mindezt elsődleges források tartalmának ismertetésével teszi a szerző; a 19. század szakmai, tudományos jelentőséggel bíró ismert vagy kevésbé ismert személyeinek munkásságát, azok tartalmát mutatja be. Írásos dokumentumokkal dolgozik vizsgálódásában, mint például a felvilágosodás korában megjelent múvek tanítóképének bemutatása, néhány reformkori, magyar nyelvú neveléstankönyv, illetve folyóirat tartalmának ismertetése. A narratív eszköz lehetôvé teszi a szerző számára az adott pedagógusszerep-elvárások és a gyermekkép ábrázolásának hangsúlyossá tételét és körvonalazását. Az egyes pedagógusi attitúdök pedig nem csupán önmagukban vizsgálhatók, hanem a narratívák összevetése által képet kaphatunk a korabeli pedagógia közgondolkodásáról. A nevelői alakok jellemzői olyan eszközökkel ábrázolhatók így, melyek a kulturális emlékezet részévé teszik a mintapedagógus alakját. Ezáltal pedig egy képet kaphatunk a 19. századi nevelőről alkotott vélemények egyezéséről, különbözőségéről, akár a különböző forrástípusokon belül vagy azok között, hiszen például egyetlen folyóirat szerzői is másképp vélekedhetnek a tanítóval kapcsolatos elvárásokról, és persze másképp prezentálhatják véleményüket egy neveléstankönyvben, mint egy folyóiratban. Ezenkívül tanítói életútleírásokat mutat be a szerző, az adott korszak tantóinak szellemiségét idézve 144 életút feltárásával. Célja nem egyfajta mélyfúrásos elemzés volt, hanem a különböző típusú forrásokban (neveléstankönyvek és folyóiratszövegek) interpretált narratívák ismertetése és összehasonlítása. Különböző szempontok vagy mondhatni: kódok lehetővé tették a komparativitást, ezek a szövegekből adódtak, a szövegek adták azokat. „A forrásokból kiválasztott „kulcsmondatok” képezik az elemzés alapját.” (Dombi, 2012. 75. o.). A szerző fó célja ezzel egy olyan összefoglalás készítése volt, amelyben megjelenik az ideális elmélet és konkrét gyakorlat elvárása a tanító múködésével, a tanítói hivatás úzésével kapcsolatosan. A könyvek és a folyóiratok narratívái pedig a tanító szerepfeladataival kapcsolatos összehasonlításra adtak lehetőséget olyan értelemben például, hogy milyen módon fogalmaznak az egyes forrásokban, mire helyezik a hangsúlyt a nevelői szerep kapcsán, megfigyelhető-e fejlődés a gyermekközpontú pedagógiai attitúd kialakulásában, megszilárdulásában. Láthatjuk, hogy a narratívák ismertetése, értelmezése, egymással való összehasonlítása bizonyos szempontok alapján lehetőséget biztosít egy adott témán belüli mintáztok felmutatására. Ez azt jelenti, hogy ha nem is általános igaz- 
ságok keresése a cél az adott kutatás során, akkor is hasznos és progresszív tartalmakra lelhetünk, mint adott esetben egy adott szakértői réteg véleményformálása által kirajzolódott gyermekkép-tanítókép megismerése. Ahogy Hayden White fogalmaz, a narratíva választ adhat, hogy hogyan lehet a tudást szavakba önteni (White, 1996).

Narratív szemléletû́ pedagógiatörténeti kutatásnak tekinthető Méreg Martin tanulmánya Schultz Imre pécsi tanítóképző intézeti tanár önéletírásának elemzéséről (Méreg, 2013). A személyes narratívák, élettörténetek kutatását a tematikus megközelítésú narratív szemléletú kutatások közé sorolják (Riessmann, 2008). Méreg Martin kutatásnak kettős célja volt: egyrészt a tanári identitás elemeinek a szöveg megalkotásának sajátosságain keresztül történő megragadása, másrészt a narráció elemeinek vizsgálata, kategóriarendszer kidolgozása, amely „lehetôvé teszi a szöveg tartalmi és strukturális elemeinek elkülönítését és a közöttük levő viszonyrendszer vizsgálatát, ebből kiindulva pedig rá lehet mutatni az önkép konstruálásának egyedi és általános vonásaira" (Méreg, 2013). Az önéletrajzi szöveg mint személyes dokumentum kínálta elemzési lehetőségek közül tehát Méreg Martin egy olyat választott, amely a szóban forgó önéletírást mint narratívumot vizsgálta a szöveg szerkezeti és tartalmi jellegzetességeinek feltárásával. A szerkezet elemzése „az időben való előrehaladás, az események egymásra következése és a közöttük levő ok-okozati viszony" (Méreg, 2013) megmutatását jelentette, ahogy az önéletrajz írója szakmai előrehaladását leírta. A tanulmány szerzője feltárta, hogy ez az egymást követő életszakaszokat rögzítő önéletírás tudatosan egy fejlődési folyamatot, ívet örökített meg, és elemzése szerint „a fejlődéselv következetes érvényesítése párhuzamba állítható a keresztény történetírás teleologikus szemléletével." (Méreg, 2013). Az önéletrajz tartalmi elemzése során a tanulmány szerzője olyan nyelvi kategóriákat különített el, vett észre az önéletrajzban, amelyek a jó és rossz pedagógus, az egykori és a korabeli tanítóképzés dichotómiáit rögzítették. Ez a tartalmi elemzés nem kvantitatív, hanem a kvalitatív tartalomelemzés egy formájának tekinthető, hiszen e tematikus mintázatok kiemelése történt meg. E kutatás egyúttal arra is rávilágít, hogy a narratív szemléletú történeti kutatás kutatásmódszertani megvalósítása - ahogy korábban már szó volt róla - különböző módszerek megfelelő alkalmazását jelentheti.

Narratív szemléletû́ kutatásnak tekinthetjük a Golnhofer Erzsébet és Szabolcs Éva által közösen megjelentetett forráskiadvány bevezető tanulmányában alkalmazott néhány elemzési szempont eredményét. A forráskiadvány 117, 1947 és 1949 között készült, az iskolai emlékekre történő visszaemlékezést tartalmazott (Golnhofer és Szabolcs, 2009a; 2009b). A visszaemlékezések egy konkrét témakör, az iskola világa köré rendeződött gondolatokat, élményeket, tapasztalatokat rögzítenek egy felmérés - korabeli szóhasználattal ankét - kérdéseire kifejtő választ adva. E szövegek önmagukban és együttesen is narratívák; mint visszaemlékezések hordozzák a létrehozójuk által konstruált, iskolával összefüggő múltjukat. A szövegek létrehozói egyszerre szereplői e narratíváknak, és megfigyelői, ér- 
telmezői is a leírt, iskolával, tanárokkal, tanítókkal kapcsolatos eseményeknek, élményeknek. Ahogy korábban szó volt róla, a visszaemlékezések tanulmányozásakor időhorizontok találkozása történik, mind a visszaemlékezők, mind a kutatók szempontjából. A történeti idő különböző metszeteinek egymásba érésének lehetünk tanúi, de látnunk kell a személyes idő, a „valóság egyéni birtokba vétele" (Golnhofer és Szabolcs, 2009b) fontosságát is, amelyre a visszaemlékezők vissza-visszatekintenek, és ez a visszatekintés a megélt idő tartalmát, jelentőségét, kiterjedését módosítja, és a múlt-jelen-jövő dimenzióit folyamatosan mozgásban tartja. Az elemzett visszaemlékező szövegekben megjelentek az emlékezet lezáratlanságát, mozgását, lehetséges irányait, alakító erejét mutató gondolatok (Golnhofer és Szabolcs, 2009b).

A narratív szemlélet térhódítását bizonyítja, hogy az utóbbi években jó néhány doktori disszertáció is e témában íródott, és az ezekben megjelenő kutatások a narrativitás témáját járják körül változatos aspektusokból.

Baska Gabriella doktori disszertációjában (2007) kvalitatív szövegelemzés segítségével, elsődleges források analizálásával egy, a századfordulón aktív és elhivatott néptanító, Budai Elek életútját kísérelte meg elénk tárni, illetve tágabb kontextusban, általában a korabeli tanítóságról alkotott társadalmi képet interpretálta az olvasóknak. A tanító munkásságának elismeréséül volt kollégái, ismerôsei a halála után Nefelejcs címmel megjelent emlékkötetben tisztelegtek előtte. A kötetben megjelenő szövegek egyfelől emléket állítottak Budai Eleknek, segítettek megőrizni, megörökíteni alakját, cselekedeteit, munkásságát, másfelől magukban foglalták a szerzők saját véleményét, álláspontját az adott témához, a tanítósághoz kapcsolódóan. E szubjektív megnyilatkozások által keletkezett szövegeket kvalitatív szövegelemzéssel analizálta a szerző, melynek során lehetőség nyílt interpretálnia azt, hogy „a néptanítói szerepről, pályáról, szakmáról folyó dualizmus kori diskurzusnak milyen elemei mutathatók ki" (Baska, 2007. 3. o.) a forrásokból. Tehát a kutatás fő célja annak feltárása volt, hogy a tanítóval kapcsolatosan megjelent szövegek, narratívák kvalitatív tartalomelemzésével milyen kép tárul elénk a 19. és 20. század fordulóján jelen lévő tanítói pályához való viszonyulásról. A szövegek (például alkalmi versek, búcsúbeszédek, visszaemlékezések) kvalitatív vizsgálata tartalomelemzéssel és metaforaelemzéssel valósult meg. A tartalomelemzés lépései, fázisai (kategorizálás, kódolás) kiegészültek a metaforák gyújtésével, a metaforaelemzéssel, mely a kutatás szempontjából azért is igazán érdekes és fontos, mert a metafora a szövegalkotó és a szövegolvasó számára is nyújthat rejtett tartalmakat, "forrása talán éppen a tudatalatti" (idézi: Baska, 2007. 116. o.). A kutatásban szereplő szövegkorpusz effajta vizsgálatával egy újabb érdekes, izgalmas megközelítést ismerhettünk meg a narratívák elemzéséhez kapcsolódóan, melynek során a szerző egy olyan eredményre jutott, mely akár mintaattitúdként szolgálhat a mai tanítógenerációnak, miszerint a szövegek alkotóinak tudatában a tanító egy kultúrhérosz, egy olyan hős, aki értékekkel rendelkezik, értékeket, tudást közvetít a tanítványai, a környezete felé. 
Nóbik Attila (2010) a magyar neveléstörténet-írás történetének egy részével foglalkozik PhD-értekezésében. Tizenöt szerző húsz megjelent kötetét vizsgálta, elemezte 1867-től 1956-ig terjedő időintervallumban abból a célból, hogy ezen írások milyen kulturális emlékezeti sajátosságokat, szociális reprezentációkat mutatnak a vizsgált időszakon belül. Ahogy a szerző idézi: „Moscovici szerint »A szociális reprezentációk a mindennapi életből eredő koncepcióknak és magyarázatoknak az egyének közötti kommunikációban kialakuló halmazai.«" (idézi: Nóbik, 2010. 49. o.). Vagyis ezáltal képet kaphatunk egy adott csoport, jelen esetben a neveléstörténészek, világról alkotott képéről, melynek kifelé való közvetítése, megjelenítése hatással bír a közösségre, társadalomra egyaránt. A szerző kiemeli, hogy a narrativitás hangsúlyozásával nem a történetírói hitelesség válik kérdésessé, hanem az objektivitás. Ugyanis például egy narratíva keletkezésekor vagy elemzésekor nem egyetlen és kizárólagos igazság létezik, hanem számos interpretáció megjelenhet, és másképp értelmezheti az adott szöveget az egyik kutató, mint a másik: „Nem a végletes elfogultságot legitimálja, hanem azt hangsúlyozza, hogy a történész a történet megalkotásánál szükségszerúen valamely nézőpontba helyezkedik, és ebből a szempontból próbálja elemezni a forrásait, amelyek szintén természetszerúleg egy vagy több, de nem az összes lehetséges nézőpontot tükrözik." (Nóbik, 2010. 40. o.). A dolgozat fő kérdéskörei ezen elméleti megalapozottság tekintetében a vizsgált időszakban: a neveléstörténet-írás alakulásának, múködésének feltárása, egyáltalán milyen neveléstörténeti kánont halmozott fel a magyar neveléstörténet-írás a kialakulása óta a tankönyvekben, például a tematikát tekintve. Ezen kívül a vizsgálat tárgyát képezte a neveléstörténeti kánonban megjelenő klasszikusok szerepének kiemelése, illetve ami a kvalitatív szövegek elemzésekor lényeges vizsgálati szempont lehet: az egyes szerzők nyelvhasználatának vizsgálata a kánon konstruálása során. Ahogy a szerző maga is megfogalmazza, a dolgozat egyik legfőbb haszna az, hogy azon túl, hogy a neveléstörténet alakulását tanulmányozza, a múlt alaposabb megismerését elősegíti, a jelen pedagógiáját segíti a hasznos és helyes módszerek, tartalmak kiemelésével és ismertetésével. A szerző vizsgálta például a különböző korszakokban jelen lévő pedagógiai klasszikusokat, az ő időről időre történő szerepük változását, hiszen a pedagógusszakma professzionalizációja során kialakuló szakmai közösség gondolatvilágának alakulásában fontos szerepet töltöttek be a klasszikusok (mint például Comenius, Rousseau, Herbart). További érdekes tartalma a kutatásnak a tankönyvek hangvételének, mérőszavainak (például pedagógusokra vonatkozó jelzők megjelenése) vizsgálata, amely szintén képet adhat egy-egy adott korszak főbb pedagógiai céljairól, esetleg ideológiai közvetítéséről.

Kolosai Nedda disszertációjában narratív interjúk tartalomelemzésével egy társadalmi jelenség, az 1950-es évek kisiskoláskorának individuális reprezentációját, szubjektív megélését igyekezett megmutatni (Kolosai, 2013). A narratív szemléletú elemzés nyelvi mintázatok feltárását jelentette az interjúk szövegéből. Az interjúkban megjelent közös élményvilágot egy narratívumkészlet részé- 
nek tekintette, és Assmann nyomán úgy értékelte a szerző, hogy az ezekben őrzött kollektív emlékezeti tartalmakhoz jutott el. Ilyen, mintázatok nyomán kiemelhető tartalmak voltak például az iskola tárgyi és téri struktúrája, a tanító személyére való emlékezés vagy a korszak történelmi fordulataira való visszaemlékezés. A visszaemlékező interjúszövegek narratívaként történő kezelése az elemzés során lehetővé tette a megjelenő különböző időhorizontok tudatosítását, a múltból „átkiáltott üzenetek” és ezekre a jelenből történő reflexió találkozását. E munkában jól észrevehető a pedagógiatörténeti és a pszichológiai megközelítés kettőse, a két tudományterületen egyaránt mutatkozó narratív szemléletú tudományosság és annak kutatásmódszertani alkalmazása. A szerzőt pszichológusként legmélyebben az érdekli, azt vizsgálta, vajon az emberek hogyan konstruálják múltjuk, jelenük és az ezek várakozási horizontján alakuló jövőjük valóságát. E mentén a második világháború időszaka körüli iskolaképet szerette volna mozaikszerúen, kis, személyes történetek szisztematikus feldolgozásával bemutatni. Kolosai kiemeli, hogy általában a narratívákat feldolgozó kutatásokban „annyi igazság van, ahány személy azt keresi” (Kolosai, 2015. 97. o.), vagyis egy-egy kutató másképp interpretálhatja ugyanazon narratívakorpuszt, másképp értelmezheti, más lényeget, kódokat emelhet ki. Nem egy igazság létezik a narratívák értelmezése során: ez a posztmodern ismeretelméleti alapállás jól tanulmányozható a szerző disszertációjában.

Takács Zsuzsanna Mária 2014-ben született doktori disszertációjában (Takács, 2014) szintén narratív történetformák kutatására vállalkozott: a 20. század első felében élt falusi néptanítók életét kutatta emlékirataik és naplóik tükrében; a magyar neveléstörténet-írásban hagyományosan kiemeltnek számító néptanító téma feldolgozását vállalta a személyes emlékező források beemelésével a tanítói életutak bemutatására. A disszertáns által felhasznált források közül kettő napló és egy visszaemlékezés volt. Célja nem a naplók, memoárok analitikus szövegelemzése volt, hanem a három eltérő szövegkorpusz alapján életrajz összeállítása, bemutatása. Vagyis „,a három életút társadalomtörténetbe ágyazott bemutatására vállalkozott a disszertáció." (Takács, 2014. 178. o.). A vizsgált tanítók életében bekövetkezett fordulópontok kiemelése és a makro- és mikrovilág vizsgálata fontos tényező volt az értekezésben. A három életút eseményeinek (tanulmányok, a tanítói pályán történő kezdeti lépések, a települések lakóival való kapcsolat stb.) dokumentatív elbeszélő módszerrel történő ismertetése „a múvelődéstörténet-írásban szokatlanul sok és hosszú idézettel, dokumentumismertetéssel s hatalmas jegyzetapparátussal" (idézi: Takács, 2014) kísérletet tesz arra, hogy a különbözô, még ismeretlen szövegeket, forrásokat (például levéltári anyagok, interjúk szövegei) bevonja a tudományos diskurzusba. Ezáltal a cél, hogy a kutató, szerző a „felidézett szövegek jellege, atmoszférája, fogalomhasználata, azonosságaik és különbségeik" (idézi: Takács, 2014) segítségével ismertesse az adott kort és jelen esetben az abban az időszakban tevékenykedő tanítókat. A disszertáció egésze tehát számos, a történettudományokban alkalmazott módszert használ, melyek közül a narratívák elemzése csak az egyik. 
Takács Zsuzsanna Mária a naplókból és memoárokból származó idézetekkel kívánja illusztrálni a szerzők gondolkodásmódját, beszéd- és írásstílusát, az adott korszak hangulatát, nyelvi sajátosságait.

A narratív szemlélet elméleti hátterével való ismerkedés, az egyes társadalomtudományokban fellelhető narratív szemlélet jegyében született kutatások megismerése arra indíthatja a pedagógiatörténet múvelőit, hogy kutatási lehetőségeik határának tágítását lássák a narrativitás mint szemléletmód érvényesítésében. A múlt lehetséges olvasatainak felmutatása meg is kívánja, hogy különböző megközelítésekkel, módszeregyüttesekkel közelítsünk elmúlt korszakok világához. Az itt felvillantott néhány példa érzékelteti a pedagógiatörténeti kutatások és a narratív szemléletmód találkozásának eredményeit.

\section{IRODALOM}

Andrews, M., Squire, C. és Tamboukou, M. eds. (2012): Doing Narrative Research. Sage, London.

Baska Gabriella (2007): Egy városi néptanitó életvilága a 19. század második feléből. Doktori PhD értekezés, Eötvös Loránd Tudományegyetem Pedagógiai és Pszichológiai Kar, Neveléstudományi Doktori Iskola, Budapest. https: //doktori.hu/index.php?menuid=193\&lang=HU\&vid=382 Utolsó letöltés: 2019.04.02.

Biró Zsuzsanna és K. Pap Tünde (2007, szerk.): Posztmodern kihívások a pedagógiatörténet-írásban. Gondolat Kiadó, Budapest.

Bruner, Jerome: (2005): Valóságos elmék, lehetséges világok. Új Mandátum Könyvkiadó, Budapest.

Dombi Alice (2012): Primus inter pares. Pedagógiai professzió és programadó nevelők a 19. században. Universitas Szeged Kiadó, Szeged.

Donáth Péter (2008): Oktatáspolitika és tanitóképzés Magyarországon 1945-1960. Trezor Kiadó, Budapest. http://mek.oszk.hu/08200/08255/html/ Utolsó letöltés: 2017.05.26.

Fulda, Daniel (2014): Historiographic Narration. http: / /www . Ihn . uni-hamb urg.de/comment/reply/123 Utolsó letöltés: 2016.06.06.

Golnhofer Erzsébet és Szabolcs Éva (2009a, szerk.): Iskola és történeti emlékezet. Gondolat Kiadó, Budapest.

Golnhofer Erzsébet és Szabolcs Éva (2009b, szerk.): Múltidézés egy megtalált forrás segítségével. in: uő: Iskola és történeti emlékezet. Gondolat Kiadó, Budapest. 11-32.

Gyáni Gábor (2000): Emlékezés, emlékezet és a történelem elbeszélése. Napvilág Kiadó, Budapest.

Holstein, James és Gubrium, Jaber eds. (2012): Varieties of Narrative Analysis. Sage, Los Angeles. 
Kálmán Orsolya (2009): Egyetemi hallgatók társas világa - ahogy a tanár szakos hallgatók elmesélik. in: Szabolcs Éva (szerk.): Ifjúkorok, gyermekvilágok I. Eötvös József Könyvkiadó, Budapest. 94-127.

Kim, Jeong-Hee (2016): Understanding Narrative Inquiry. Sage, Los Angeles.

Kolosai Nedda (2013): Kisiskoláskor és történeti idő. az 1950-as évek kisiskoláskorára vonatkozó narratívák elemzése. PhD disszertáció https://ppk. elte.hu/file /kolosai_nedda_ilona_dissz.pdf Utolsó letöltés: 2016.08.11.

Méreg Martin (2013): Tanítóképzés és tanári pálya emlékezete: egy pécsi tanítóképző intézeti tanár önéletírásának értelmezési lehetőségei. In: Méreg Martin-Somodi Imre-Vörös Katalin (szerk.): Tanulmányok a neveléstudomány pécsi mûhelyéből. Pécsi Tudományegyetem, Oktatás és Társadalom Doktori Iskola. Pécs. 34-56.

Mórocz Gábor (2014): Ricouer és a braudeli hosszú idő problémája. Belvedere Meridionale. XXVI. 3. sz. 129-138. DOI 10.14232/belv.2014.3.9 http://dx.doi .o rg/10.14232/belv.2014.3.9 Utolsó letöltés: 2017.05.26.

Nóbik Attila (2010): Klasszikusok és kánonképzés a magyar neveléstörténeti tankönyvekben. (1867-1956). Doktori értekezés. Szegedi Tudományegyetem Bölcsészettudományi Kar, Neveléstudományi Doktori Iskola, Neveléstörténeti Doktori Program, Szeged.

Pászka Imre (2007): Narratív történetformák. Belvedere, Szeged.

Pukánszky Béla szerk. (2008): A neveléstörténet-írás új útjai. Gondolat Kiadó, Budapest.

Riessman, C.K. (2008): Narrative Methods for the Human Sciences. Sage, Los Angeles and London.

Rüsen, Jörg (1999): A történelem retorikája. In: Thomka Beáta (szerk): Narratívák 3. A kultúra narratívái. Kijárat Kiadó, Budapest. 39-50.

Szabolcs Éva (2016): Narratíva és pedagógiatörténet. In: Garai Imre, Vincze Beatrix és Szabó Zoltán András (szerk.): Hiteles pedagógia. Tanulmányok Golnhofer Erzsébet tiszteletére. ELTE Eörvös Kiadó, Budapest. 79-83.

Takács Zsuzsanna Mária (2014): Falusi néptanítók élete a 20. század első felében emlékirataik és naplóik tükrében. Doktori (PhD) értekezés, Pécs. http://pea.lib. pte.hu/bitstream/handle/pea/14687/takacs-zsuzsanna-maria-phd- 2015. pdf?sequence=1\&isAllowed=y Utolsó letöltés: 2017.05.26.

White, Hayden (1975): Metahistory. The historical imagination in nineteenthcentury Europe. The Johns Hopkins University Perss, Baltimore § London.

White, Hayden (1984): The question of narrative in contemporary historical theory. https : //www2 . southeastern . edu/Academics/Faculty/jbell/white. pdf Utolsó letöltés: 2016.06.06.

White, Hayden (1996): A narrativitás szerepe a valóság reprezentációjában. Fordította: Deák Ágnes. Aetas/I. http: //www . aetas.hu/1996_1/white.htm Utolsó letöltés: 2018.02.23. 